\title{
Miocene drainage reversal of the Amazon River driven by plate-mantle interaction
}

\author{
G. E. Shephard ${ }^{1 \star}$, R. D. Müller ${ }^{1}$, L. Liü ${ }^{2 \dagger}$ and M. Gurnis ${ }^{2}$
}

\begin{abstract}
Northern South America experienced significant changes in drainage patterns during the opening of the South Atlantic Ocean. Disappearance of a mega-wetland in the western Amazonian basins was followed by the formation of the eastward-draining Amazon River, which has been attributed to Andean uplift ${ }^{1-5}$. However, South America's westward motion over cold, dense subducted slabs implies that regional subsidence and uplift east of the Andes may have been driven by mantle convection. Here we use a coupled model of mantle convection and plate kinematics to show that dynamic subsidence of up to $40 \mathrm{~m} \mathrm{Myr}^{-1}$ initially formed the Amazonian mega-wetland. In our model, the sustained westward motion of continental South America over subducted slabs resulted in rebound of the Amazonian mega-wetland region at rates of up to $40 \mathrm{~m} \mathrm{Myr}^{-1}$ after 30 million years ago, paired with continued subsidence of the eastern Amazonian sedimentary basins at 10-20 $\mathrm{m} \mathrm{Myr}^{-1}$. The resulting progressive tilt of northern South America to the east enabled the establishment of the Amazon River, suggesting that mantle convection can profoundly affect the evolution of continental drainage systems.
\end{abstract}

During the Early Miocene (from $\sim 23 \mathrm{Myr}$ BP), an inland fluviolacustrine/marginally marine Amazonian system partially flooded northwest South America with regional drainage mainly northwards towards the Caribbean ${ }^{1-4}$. This Amazonian megawetland existed at least from the Middle to Late Miocene ${ }^{1,2}$ when the dominant fluvial drainage switched to its present course towards the Atlantic. This shift, initiating the fluviolacustrine system that is now the Amazon River is supported by sediment provenance, palaeo-transport direction and biostratigraphic studies ${ }^{1-3,5}$. The timing of this onset is estimated from offshore sedimentary records between 10.6 and 9.7 Myr вP (ref. 6). Any possible AmazonianCaribbean connection was fully closed by the Late Miocene ${ }^{2}$, with the Amazon River reaching its present shape and size from the Pleistocene onwards ${ }^{2,7}$ ( 2.4 Myr BP). During the Early and Middle Miocene a restricted eastward-flowing palaeo-Amazon River may have drained to the Atlantic coast ${ }^{7}$. Stratigraphic data suggest that this fluvial system extended westward until limited by the Purus $\operatorname{arch}^{7}$ (Fig. 1), a structural high that separated the Solimões and Amazonas basins and restricted the Amazonian mega-wetland to the west and the palaeo-Amazon River to the east.

The main Miocene changes in drainage patterns, and the formation of the Amazon River, are commonly attributed to uplift in the northwest Andes ${ }^{5,8-11}$. It has been proposed that the uplift of the Eastern Cordillera caused flexural subsidence in the foreland basins, and redirected a significant portion of the northwest Amazonas basin drainage, along the northward-flowing Palaeo-Orinoco and Magdalena rivers, to the east ${ }^{2}$. In addition, it has also been suggested that Amazon landscape evolution can be attributed to Early Tertiary to Holocene intraplate tectonics, including subsidence associated with a low-rate extension that contributed to a structural low ${ }^{12}$. The Late Miocene $(\sim 11$ Myr BP $)$ is also well documented for a significant drop in sea level, which would have contributed to the disappearance of the Amazonian mega-wetland and marine incursions ${ }^{13,14}$, but could not have caused a fundamental change in the continental drainage pattern. The mechanism driving the time-progressive tilt of the world's largest drainage system remains insufficiently described and here we present a new and unconventional explanation.

Instantaneous models of dynamic topography, mapping largescale surface depression or uplift driven by mantle convection, predict one of Earth's largest topographic lows over South America $^{15}$, but its time dependence is unknown. To unravel the history of mantle-convection-driven continental elevation and tilting, we use a geodynamic model that integrates plate motions, dynamically evolving plate boundaries and mantle tomography. We generate estimates of palaeo-topography by adjusting a present-day digital elevation model with time-dependent dynamic topography and estimates of global sea level.

The first approximation of initial conditions for seismic structure at earlier times can be optimized using a simple backward integration of the governing equations ${ }^{16}$. The initial condition is further refined through an iterative forward-inverse optimization, adjoint, algorithm. The starting point of the adjoint model is a present-day mantle density and effective temperature field converted from seismic velocity perturbations ${ }^{17}$.

Forward in time, as South America migrates westward, the model shows the development of temperature anomalies under the continent due to subduction of the Farallon, Phoenix, and most recently Nazca plates (Fig. 2 and Supplementary Fig. S1). The evolution of thermal anomalies in the adjoint model links slab volumes to particular tectonic stages of subduction. The viscous forces imparted on South America by the continent's gradual passage over these slabs sinking in the mantle are reflected in negative surface dynamic topography (Supplementary Fig. S2), resulting in long-wavelength subsidence over the Cenozoic era (Fig. 3 and Supplementary Fig. S3). At present, the bulk of the underlying slab (Fig. 2) is between $80^{\circ} \mathrm{W}$ and $60^{\circ} \mathrm{W}$ longitude, imparting a significant influence on surface topography of the western portion of South America. Broad subsidence at a rate of approximately $20 \mathrm{~m} \mathrm{Myr}^{-1}$ across the northern regions of South America is generated from $60 \mathrm{Myr}$ вр. This signal intensifies in the north and northwest of the continent to generate a band of easterly sweeping subsidence (up to $30-40 \mathrm{~m} \mathrm{Myr}^{-1}$ ) by $30 \mathrm{Myr}$ вр. This long-term subsidence across both foreland and intracratonic basins provided the accommodation space for the formation of the Amazonian mega-wetland and associated marine incursions.

\footnotetext{
${ }^{1}$ School of Geosciences, University of Sydney, Sydney, New South Wales 2006, Australia, ${ }^{2}$ Seismological Laboratory, California Institute of Technology, Pasadena, California 91125, USA. †Present address: Institute of Geophysics and Planetary Physics, Scripps Institution of Oceanography, University of California, San Diego, La Jolla, California 92037, USA. *e-mail: grace.shephard@sydney.edu.au.
} 
a
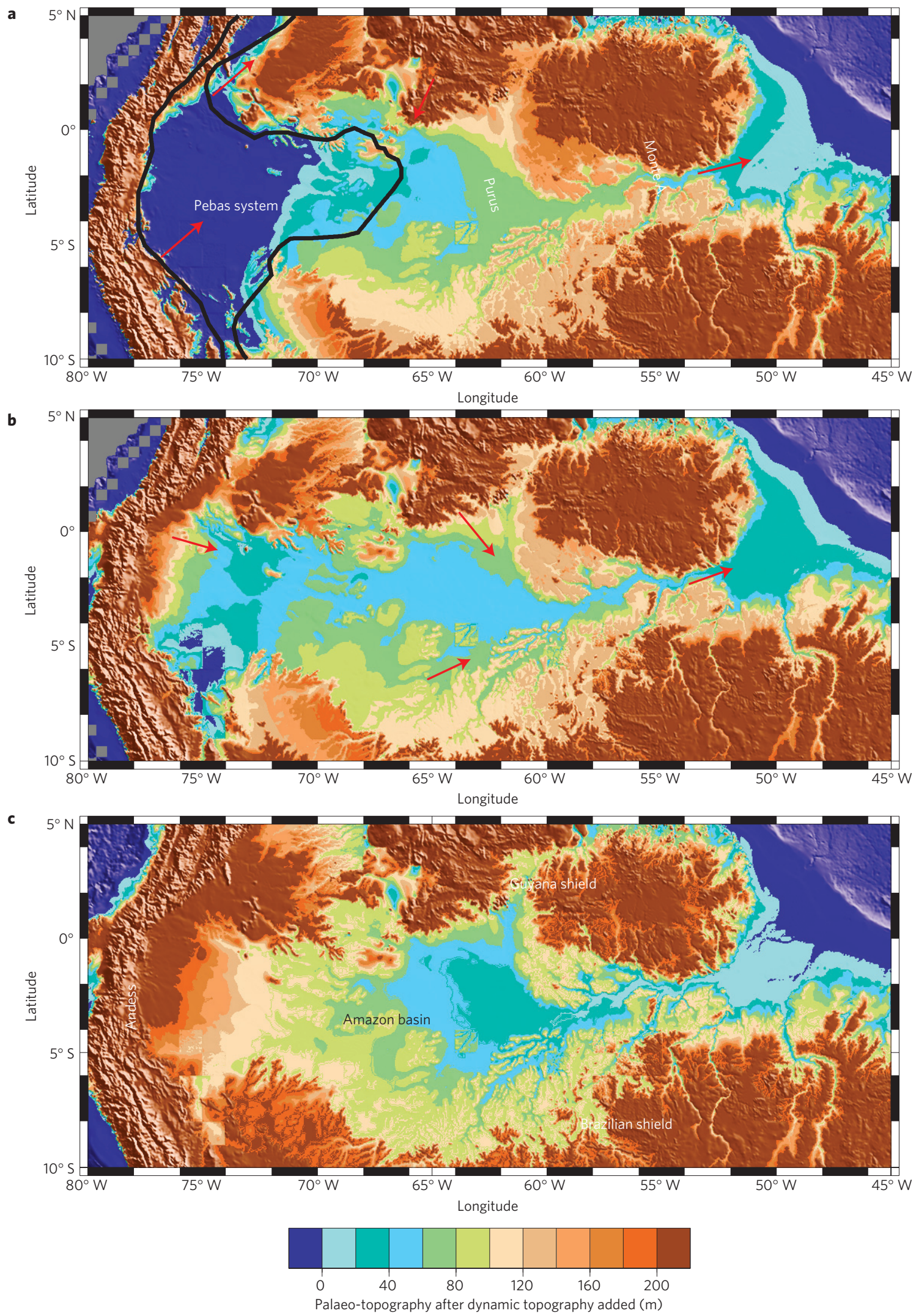

Figure 1 | Palaeo-geography of the Amazon region. a-c, Palaeo-drainage and palaeo-topography of the Amazon region at 14 Myr BP (a), 6 Myr BP (b) and present-day (c), in a fixed South America reference frame. Long-wavelength dynamic topography signal causes significant subsidence in the central and eastern Amazon region, and uplift adjacent to the Andes. In the calculation of our palaeo-topography, we do not remove any sediments or orogenic building, and therefore our predictions of inundation are underestimated. The approximate extent of the Miocene Amazonian mega-wetland is illustrated by the black outline (adapted from ref. 29). The Purus arch and Monte Alegre arch included for reference. The red arrows delineate the sediment influx direction in the Amazonian sedimentary basins (adapted from ref. 2). 

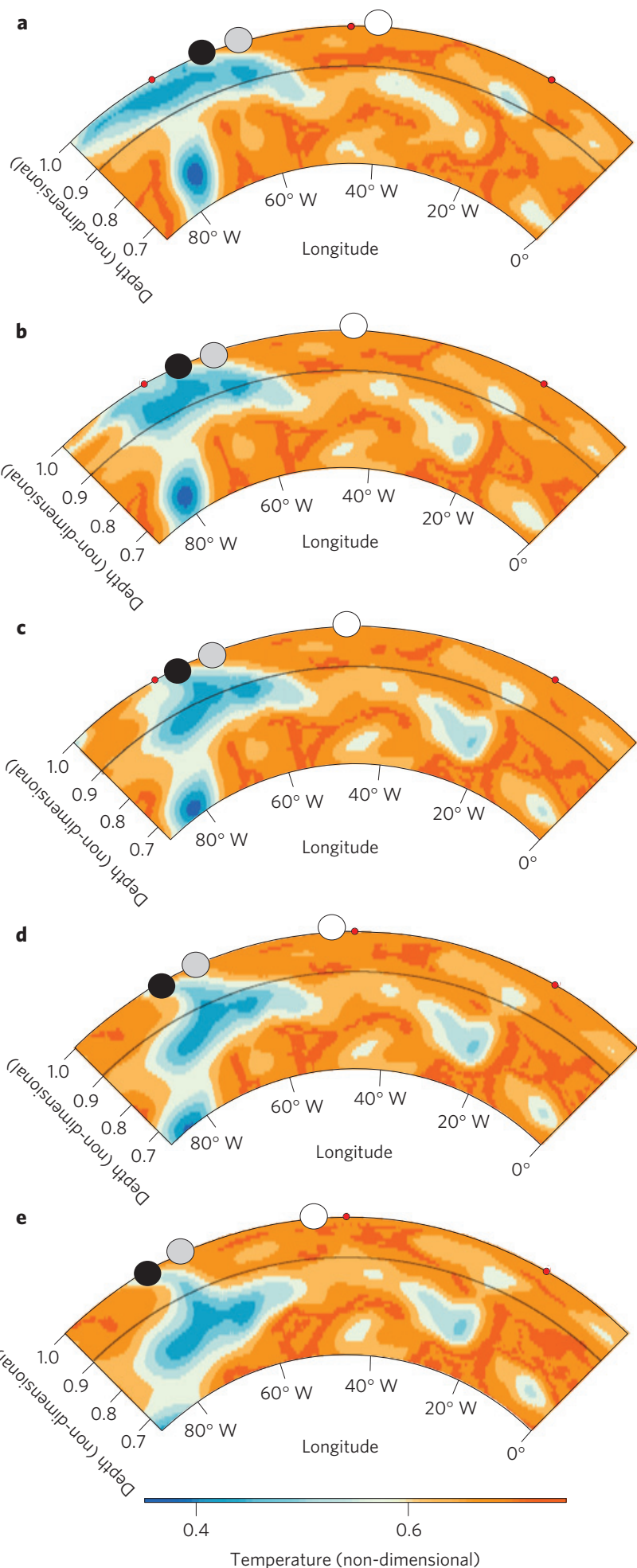

Figure 2 | Temperature structure underlying South America.

a-e, Non-dimensional model mantle temperature cross-sections though the Equator at 40 Myr BP (a) 30 Myr BP (b), 20 Myr BP (c), 10 Myr BP (d) and present-day (e). The blue colours represent negative thermal anomalies (subducted slabs), whereas the dark orange colours represent positive thermal anomalies (ambient mantle is light orange). The circles represent the approximate longitudinal locations of the (present-day) Andes (black), the centre of the (Miocene) Pebas depositional system (grey) and the mouth of the (present-day) Amazon River (white), on the overriding South American plate. Small red circles are fixed marker points to show relative movement in successive panels.
By inundating our modelled palaeo-topography with a eustatic sea-level curve ${ }^{14}$ (Fig. 1 and Supplementary Fig. S5), we obtain a palaeo-geography estimate that can be compared with geologically mapped palaeo-depositional environments. Since at least $45 \mathrm{Myr}$ в our modelled palaeo-geography shows increasing inundation of northwestern South America, and between $22 \mathrm{Myr}$ and $14 \mathrm{Myr}$ в matches the mapped geometry of the Amazonian mega-wetland (Fig. 1). Without correcting palaeo-topography for mantle-driven dynamic topography, inundation of northern South America using present-day topography (Supplementary Fig. S4) is significantly offset with respect to mapped palaeo-coastlines. This is particularly true of the central and eastern regions of South America where Andean orogenic processes are largely absent. The modelled topographic low would have accommodated most of the drainage and/or marine incursion of the central and western regions of the continent towards the north (Fig. 1). Although we did not remove the effect of Andean mountain building when generating palaeo-topography, our results provide a good prediction on the timing and eastern geometry of the Amazonian megawetland. Despite this evolving broad dynamic topography low being contemporaneous with flexural subsidence from Andean uplift, the wavelength of the dynamic signal extends further east, beyond the domain of the foreland basin. The removal of sediment (or orogenic growth) back through time would further decrease palaeo-topography and would lead to additional overinundation. A mechanism restricted to the western margins seems insufficient to explain such a continental tilt and we suggest that dynamic topography is the main driving factor in longwavelength changes in topography and the formation of the Amazonian mega-wetland.

Towards the northeastern side of the continent, our palaeotopographies reconstruct a structural/topographic high preventing any drainage linking the Caribbean and Atlantic from at least $22 \mathrm{Myr}$ to 14 Mуг вр (Fig. 1). The small connection to the Atlantic shown in our model is an artefact of using present-day topography, which has been shaped by erosion of the Amazon River. A structural high is likely to have been continuous across the Brazilian margin, comprising the Purus and Monte Alegre arches. Our model also supports the idea that a restricted eastward-draining palaeo-Amazon River may have existed during the Early to Middle Miocene to the very east of this structural high ${ }^{7}$.

In contrast to broad subsidence across central and eastern South America, our geodynamic model predicts a narrow band of uplift at a rate of $40 \mathrm{~m} \mathrm{Myr}^{-1}$ since approximately $30 \mathrm{Myr} \mathrm{BP}$, originating along the western coast of South America (Fig. 3). This is due to the westward translation of the continent past the bulk of the sinking slab mass, causing easterly migrating surface rebound across the Andes, extending east to $67^{\circ} \mathrm{W}$ (Fig. 2). Although subduction along the western margin of South America has occurred since the Late Cretaceous ${ }^{18}$, our geodynamic models imply that the influence of subducted slabs on the surface topography diminishes quickly as slabs sink deeper, and that topographic variations are more affected by the rapid westward motion of South America over descending slabs. This is evident through our model with decreasing magnitudes of subsidence and uplift over time, which also migrate eastwards (Fig. 3).

In addition to eastward-migrating mountain building $2,5,9,19,20$, this eastward-propagating dynamic uplift would have significantly reduced any marine incursions, uplifted the Amazonian mega-wetland, caused a significant re-organization of drainage across the northern region of the continent, and may account for increased eastward sediment provenance and rates of sedimentation at the Amazon fan during the Early Pliocene ${ }^{7}$. The reduction of the Amazonian mega-wetland, as reconstructed by our palaeo-geographic maps, is most pronounced between $14 \mathrm{Myr}$ and 6 Myr вP (up to $200 \mathrm{~m}$ of uplift; Fig. 1), which matches 


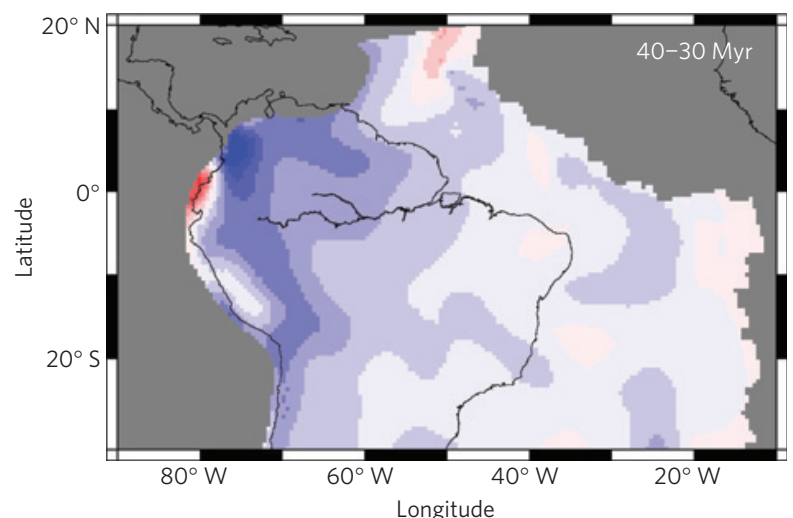

c

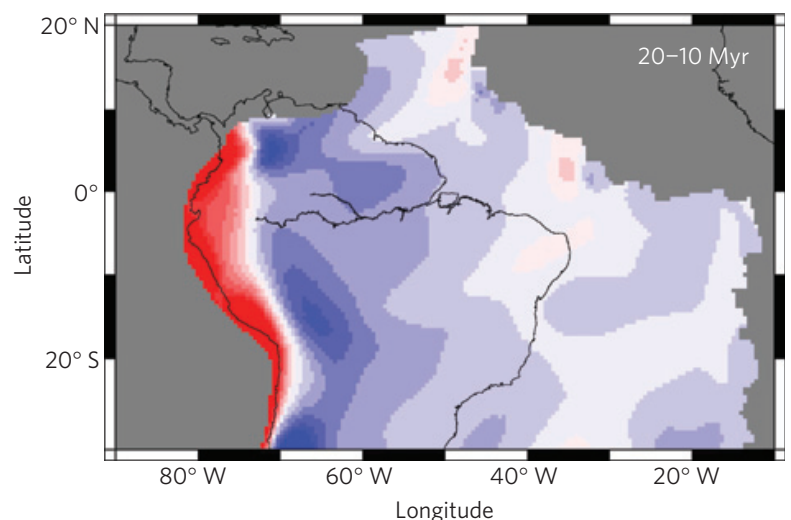

Longitude

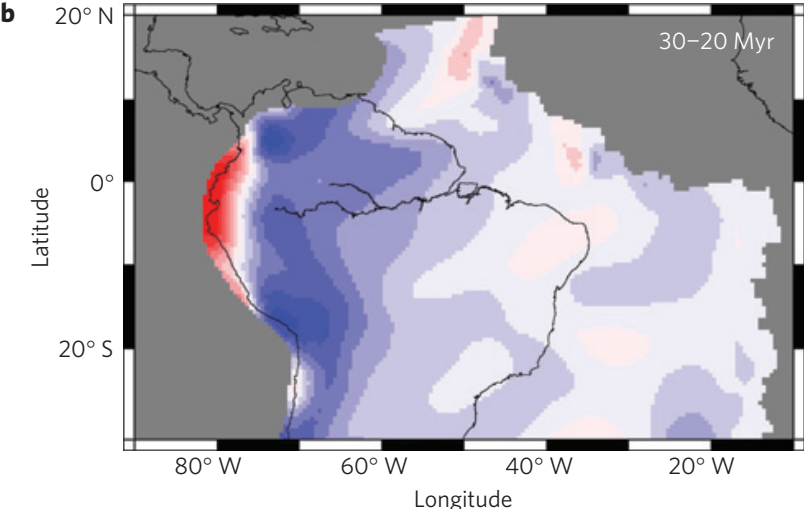

d

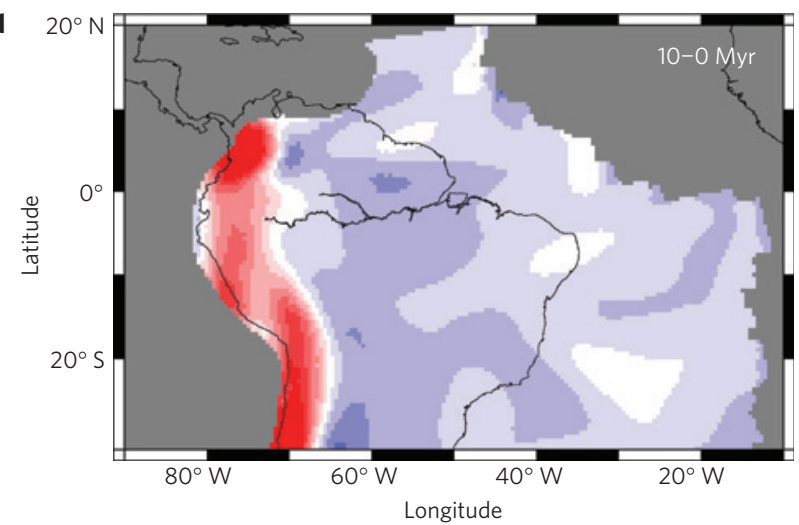

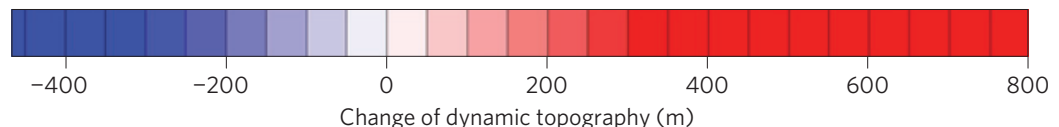

e
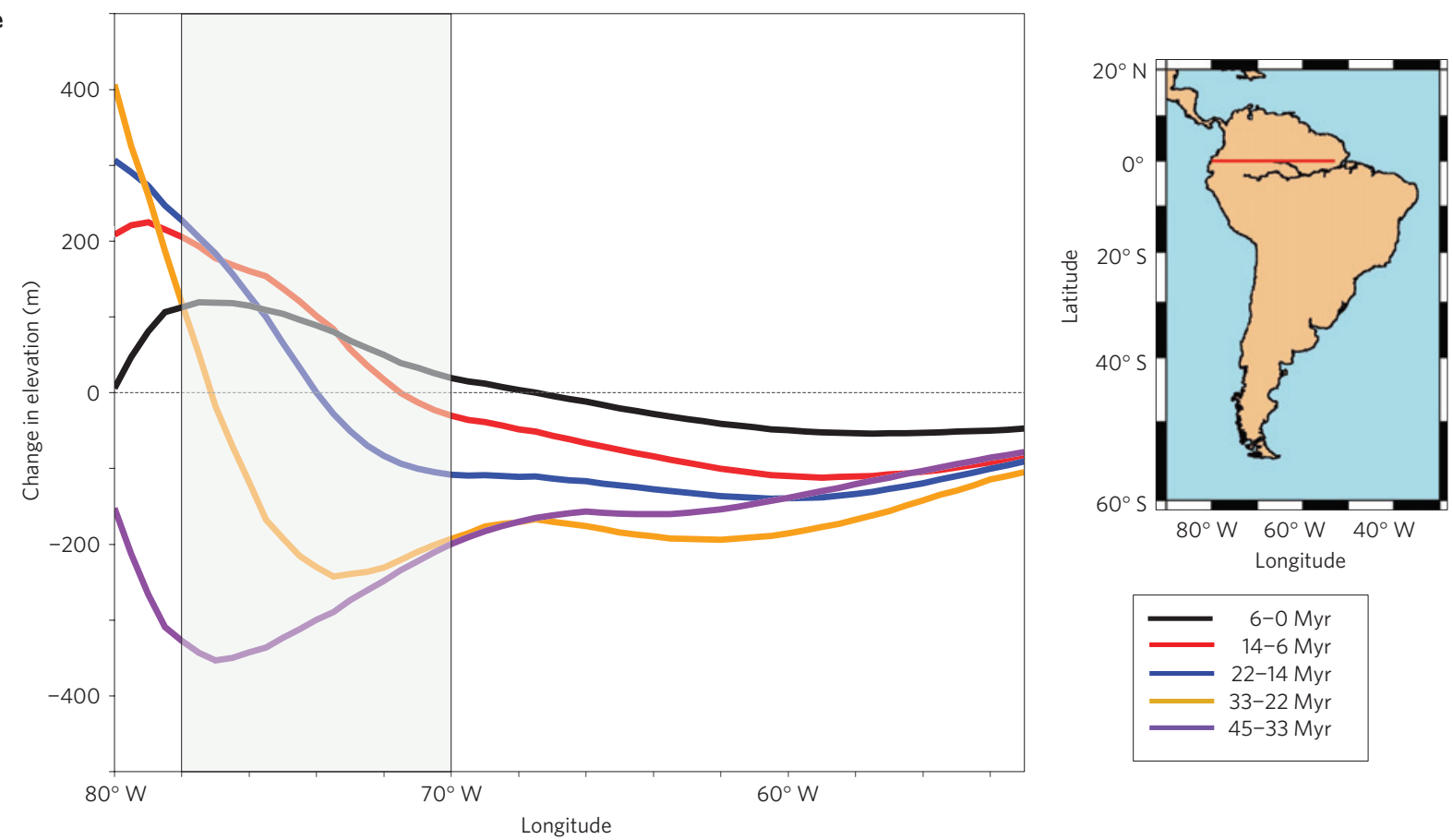

Figure 3 | Dynamic topography and change in elevation. a-d, Change in surface dynamic topography since 40 Myr BP in a fixed South America reference frame. Red indicates uplift, whereas blue indicates subsidence. Note the fixed colour palette between $\pm 300 \mathrm{~m}$, but variable maximum and minimum values. The grey areas were outside the model domain. e, Modelled change in continental elevation (derived from our palaeo-topography) at the Equator, illustrating the eastward-propagating change from subsidence to uplift in the Amazonian mega-wetland area after 33 Myr BP, and the accentuation of subsidence at the mouth of the evolving Amazon River. The grey band indicates the approximate longitudinal extent of the mega-wetland at this latitude (adapted from ref. 29). 
independent observations of Late Miocene to Pliocene uplift and disappearance of the mega-wetland ${ }^{2,9,10,13}$, and cessation of continental basin deposition ${ }^{6}$.

The magnitude, timing and spatial domain of our modelled results suggest that the evolution of the Andes and other tectonic features, such as the Iquitos $\operatorname{arch}^{5,10}$, may have been modulated by dynamic topography. Despite the long wavelengths of dynamic topography, it is possible that localized stress as a consequence of accelerated subsidence or uplift has reactivated existing basement features, or enhanced the effect of forebulge uplift ${ }^{5}$. Furthermore, the eastward migration of the Andean mountains, continued propagation of the Amazonian forebulge ${ }^{5}$, increased Late Miocene Andean uplift rates ${ }^{21}$ and increased sedimentation rates in foreland basins $^{22}$ may at least partly be a consequence of eastwardpropagating dynamic uplift. The longitudinal migration of both peak subsidence and later uplift is well demonstrated by our model (Fig. 3), with the transition of deformation from the orogen and foreland domains to intracratonic basins. Although initial eastward propagation of orogenic deformation is estimated to have reached the Eastern Cordillera between 40 and $30 \mathrm{Myr}$ в (ref. 23), and the sub-Andean basins as late as 10 to $5 \mathrm{Myr}$ в (ref. 24), we argue that the sustained magnitude and wavelength of dynamic topography is the dominant factor in driving an increase in continental long-wavelength tilt through time. For instance, the forward propagation of orogenic deformation in the past $10 \mathrm{Myr}$ is merely $74 \mathrm{~km}$ (ref. 20).

We propose that the formation of the present-day Amazon River was primarily driven by mantle-convection-driven subsidence and uplift of the western regions of South America. To a lesser extent, progressive eastward tilting of the continent was also facilitated by continued subsidence of approximately 10-20 $\mathrm{m} \mathrm{Myr}^{-1}$ of eastern South America, as it moved over slab material sinking in the lower mantle (Fig. 2). Our palaeo-geographic reconstructions show clear uplift in the west, and subsidence of the central and eastern basins of South America, from 14 Myr BP to present-day (Figs 1 and 3), facilitating the initiation of the transcontinental Amazon River. The magnitude of dynamic topography-driven subsidence, with up to $400 \mathrm{~m}$ of subsidence at the mouth of the Amazon between $60 \mathrm{Myr}$ в $\mathrm{P}$ and present, was significant enough for fluvial transport to overcome easterly structural highs.

Our reconstructed timing of major regional transgressions and regressions is supported by several independent observations $s^{6,11-13}$. Miocene sediment sources for the palaeo-Amazon River and offshore fans progressively shifted west towards central Amazonia by the Middle Miocene, connected with the central wetland regions, and reached the Andes by the Late Miocene ${ }^{6}$ in agreement with our model. This change in sediment source followed the expansion of regional drainage towards the west as facilitated by broad subsidence. In addition, sediment provenances and ages from fan deposits in the Foz do Amazonas basin ${ }^{6}$ are well accounted for by our geodynamic model.

Our geodynamic model provides a robust mechanism for driving long-wavelength topography of South America over the Cenozoic that incorporates the entire continental domain. We have successfully established that dynamic subsidence and uplift imparts significant time-dependent effects on palaeo-geography, driving changes in fluvial drainage and marine incursions. Our geodynamic model for the evolution of northern South America demonstrates that the iterative assimilation of plate kinematics, seismic tomography and regional geological data into mantleconvection models is a powerful approach to link deep Earth to surface processes.

\section{Methods}

Coupled plate kinematic/mantle convection models require initial and boundary conditions as well as mantle rheology to be well constrained. We use the adjoint
Table 1 | Parameters for adjoint model.

\begin{tabular}{ll} 
Parameter & Value \\
\hline Reference mantle density & $3,300 \mathrm{~kg} \mathrm{~m}^{-3}$ \\
$\begin{array}{l}\text { Gravitational acceleration } \\
\text { Radius }\end{array}$ & $9.81 \mathrm{~m} \mathrm{~s}^{-2}$ \\
Super-adiabatic temperature change & $6,371 \mathrm{~km}$ \\
from core-mantle boundary to surface & $400^{\circ} \mathrm{C}$ \\
Coefficient of thermal expansion & \\
Thermal diffusivity & $3 \times 10^{-5} \mathrm{~K}^{-1}$ \\
Reference viscosity & $10^{-6} \mathrm{~m}^{2} \mathrm{~s}^{-1}$ \\
Rayleigh number & $10^{21} \mathrm{~Pa} \mathrm{~s}$ \\
& $9 \times 10^{6}$
\end{tabular}

method to retrieve mantle initial conditions, and the viscosity structure is constrained by fitting dynamic subsidence inferred from stratigraphy over North America. Modelling, and subsequent visualization were achieved through a combination of software packages. We used CitcomS for the computation of mantle convection using a finite-element method ${ }^{25}$, GPlates for plate reconstruction and model boundary condition generation, and generic mapping tools for visualization and file manipulation. Our adjoint models use Grand's ${ }^{26}$ $\mathrm{S}$-wave tomographic inversion, scaled to a present-day temperature field with $2 \times 10^{3}{ }^{\circ} \mathrm{C} \mathrm{km}^{-1} \mathrm{~s}^{-1}$ (ref. 21).

The models have a four-layer mantle: lithosphere $(0-90 \mathrm{~km})$, upper mantle $(90-410 \mathrm{~km})$, transition zone $(410-670 \mathrm{~km})$ and lower mantle $(670-2,891 \mathrm{~km})$. Each layer has a reference non-dimensional viscosity of 50,1,1 and 15, respectively. Additional models were also computed with alternative non-dimensional lower mantle viscosities of 10 and 30 instead of the nominal 15 (Supplementary Figs S6-S9). The finite-element models were global, fully spherical so as to avoid edge effects that arise in regional models. The finite-element mesh was composed of 12 caps, with $129 \times 129$ nodes in the horizontal and 65 in the radial directions. The reference mantle parameters used in this South American model are based on the best-fit values for an adjoint model of North America ${ }^{17,27}$ (Table 1). The surface is isothermal and the core-mantle boundary is isothermal with mechanical free-slip conditions.

Surface velocity grids, as boundary conditions to the adjoint model, were derived from plate tectonic reconstructions ${ }^{28}$, in one-million-year increments. The palaeo-topography reconstructions were achieved by deriving grid files of surface dynamic topography from adjoint model output. At each time step, differential dynamic topography (that is, that with respect to present-day) is added to present-day topography in an attempt to recreate a palaeo-topography model.

Received 1 April 2010; accepted 22 October 2010; published online 21 November 2010

\section{References}

1. Hoorn, C. Marine incursions and the influence of Andean tectonics on the Miocene depositional history of northwestern Amazonia: Results of a palynostratigraphic study. Palaeogeogr. Palaeoclimatol. Palaeoecol. 105, 267-309 (1993).

2. Hoorn, C., Guerrero, J., Sarmiento, G. A. \& Lorente, M. A. Andean tectonics as a cause for changing drainage patterns in Miocene northern South America. Geology 23, 237-240 (1995).

3. Räsänen, M. E., Linna, A. M., Santos, J. C. R. \& Negri, F. R. Late Miocene tidal deposits in the Amazonian Foreland Basin. Science 269, 386-390 (1995).

4. Vonhof, H. B. et al. Paleogeography of Miocene Western Amazonia: Isotopic composition of molluscan shells constrains the influence of marine incursions. GSA Bull. 115, 983-993 (2003).

5. Roddaz, M., Baby, P., Brusset, S., Hermoza, W. \& Darrozes, J. M. Forebulge dynamics and environmental control in Western Amazonia: The case study of the Arch of Iquitos (Peru). Tectonophysics 399, 87-108 (2005).

6. Figueiredo, J., Hoorn, C., van der Ven, P. \& Soares, E. Late Miocene onset of the Amazon River and the Amazon deep-sea fan: Evidence from the Foz do Amazonas Basin: Reply. Geology 38, 213 (2010).

7. Figueiredo, J., Hoorn, C., van der Ven, P. \& Soares, E. Late Miocene onset of the Amazon River and the Amazon deep-sea fan: Evidence from the Foz do Amazonas Basin. Geology 37, 619-622 (2009).

8. Grabert, H. Die prae-andine drainage des Amazonas stromsystems. Muenstersche Forsch. Geolo. Palaeontolo. 20, 51-60 (1971).

9. Marshall, L. G. \& Lundberg, J. G. Miocene deposits in the Amazonian Foreland Basin (Technical comments). Science 273, 123-124 (1996).

10. Roddaz, M., Viers, J., Brusset, S., Baby, P. \& Hérail, G. Sediment provenances and drainage evolution of the Neogene Amazonian foreland basin. Earth Planet. Sci. Lett. 239, 57-78 (2005). 
11. Roddaz, M., Brusset, S., Baby, P. \& Hérail, G. Miocene tidal-influenced sedimentation to continental Pliocene sedimentation in the forebulge-backbulge depozones of the Beni-Mamore foreland Basin (northern Bolivia). J. South Am. Earth Sci. 20, 351-368 (2006).

12. Costa, J. B. S., Bemerguy, R. L., Hasui, Y. \& da Silva Borges, M. Tectonics and paleogeography along the Amazon river. J. South Am. Earth Sci. 14, 335-347 (2001).

13. Hoorn, C. Miocene deposits in the Amazonian Foreland Basin (Technical comments). Science 273, 122 (1996).

14. Haq, B. U., Hardenbol, J. \& Vail, P. R. Chronology of fluctuating sea levels since the Triassic. Science 235, 1156-1167 (1987).

15. Steinberger, B. Effects of latent heat release at phase boundaries on flow in the Earth's mantle, phase boundary topography and dynamic topography at the Earth's surface. Phys. Earth Planet. Inter. 164, 2-20 (2007).

16. Liu, L. \& Gurnis, M. Simultaneous inversion of mantle properties and initial conditions using an adjoint of mantle convection. J. Geophys. Res. 113, B08405 (2008).

17. Spasojevic, S., Liu, L. \& Gurnis, M. Adjoint models of mantle convection with seismic, plate motion and stratigraphic constraints: North America since the Late Cretaceous. Geochem. Geophys. Geosyst. 10, Q05W02 (2009).

18. Sdrolias, M. \& Müller, R. D. Controls on back-arc basin formation. Geochem. Geophys. Geosyst. 7, Q04016 (2006).

19. Dumont, J. F. Neotectonics of the Subandes-Brazilian craton boundary using geomorphological data: The Marañon and Beni basins. Tectonophysics 259, 137-151 (1996).

20. Baby, P., Rochat, P., Mascle, G. \& Hérail, G. Neogene shortening contribution to crustal thickening in the back arc of the Central Andes. Geology 25, 883-886 (1997).

21. Garzione, C. N. et al. Rise of the Andes. Science 320, 1304-1307 (2008).

22. Baby, P., Guyot, J. L. \& Hérail, G. Tectonic control of erosion and sedimentation in the Amazon Basin of Bolivia. Hydrol. Process. 23, 3225-3229 (2009).

23. Mora, A. et al. in Amazonia: Landscape and Species Evolution (eds Hoorn, C. \& Wesselingh, F.) 421-431 (Wiley-Blackwell, 2010).
24. Kley, J. Transition from basement-involved to thin-skinned thrusting in the Cordillera oriental of southern Bolivia. Tectonics 15, 763-775 (1996).

25. Tan, E., Choi, E., Thoutireddy, P., Gurnis, M. \& Aivazis, M. GeoFramework: Coupling multiple models of mantle convection within a computational framework. Geochem. Geophys. Geosyst. 7, Q06001 (2006).

26. Grand, S. P. Mantle shear wave tomography and the fate of subducted slabs. Phil. Trans. R. Soc. Lond. A 360, 2475-2491 (2002).

27. Liu, L., Spasojevic, S. \& Gurnis, M. Reconstructing Farallon plate subduction beneath North America back to the Late Cretaceous. Science 322, 934-938 (2008).

28. Müller, R. D., Sdrolias, M., Gaina, C. \& Roest, W. R. Age, spreading rates and spreading asymmetry of the world's ocean crust. Geochem. Geophys. Geosyst. 9, Q04006 (2008).

29. Wesselingh, F. et al. in Amazonia: Landscape and Species Evolution (eds Hoorn, C. \& Wesselingh, F.) 421-431 (Wiley-Blackwell, 2010).

\section{Acknowledgements}

Supported by StatOil, NSF Grant EAR-0810303 at Caltech and ARC Grant FL0992245 at Sydney.

\section{Author contributions}

G.E.S. post-processed model output and developed palaeo-geography analysis and prepared the manuscript; R.D.M. supervised the project and contributed to the manuscript; L.L. prepared and executed numerical models and contributed to the manuscript; R.D.M. and M.G. conceived project ideas and gave technical and conceptual advice.

\section{Additional information}

The authors declare no competing financial interests. Supplementary information accompanies this paper on www.nature.com/naturegeoscience. Reprints and permissions information is available online at http://npg.nature.com/reprintsandpermissions. Correspondence and requests for materials should be addressed to G.E.S. 